\title{
Determining Some Factors of the Financial Situation in the European Union Publishing Sector
}

\author{
José Ángel Sanz, ${ }^{1}$ Ana María Bedate, ${ }^{2}$ Mariano Durántez ${ }^{3}$
}

\begin{abstract}
The publishing sector is probably a cultural industry with one of the greatest economic projections due to its huge turnover and contribution to the Gross Domestic Product of countries. In order to gain a better understanding of this sector, this paper examines a sample of the most important companies belonging to this sector in the European Union, focusing on studying their economic-financial profile. In order to achieve this, multivariate statistical techniques are used to create indicators on the evolution of the main variables and financial ratios of these companies over recent years. The specific objectives are: to summarise the information in a smaller number of factors, which in turn enable us to construct a robust and reliable synthetic indicator; and investigate the relationship between the constructed index and different variables such as company age, size and localisation. The changes experienced in this sector are reflected in the obtained results and provide a richer understanding of cultural industries.
\end{abstract}

Key words: Financial Ranking, Financial Ratios, Publishing Sector, Synthetic Indicator

JEL Classification: C38, G00, Z11

Received: 3 July 2017 / Accepted: 18 January 2017 / Sent for Publication: 8 March 2018

\section{Introduction}

The publishing industry has been studied from several perspectives, whether for the purpose of understanding its performance and evolution or in order to predict its expected behaviour and adaptation to new technologies (IPA 2015, FEP 2015). However, economic and financial analyses of the sector have seldom been undertaken.

\footnotetext{
${ }^{1}$ Universidad de Valladolid, Facultad de Comercio, Departamento de Economía Financiera y Contabilidad, Plaza del Campus Universitario, 1, 47011 Valladolid, Spain, e-mail: angel@emp.uva.es, ORCID: 0000-0001-7243-8325

${ }^{2}$ Universidad de Valladolid, Facultad de Comercio, Departamento de Economía Financiera y Contabilidad, Plaza del Campus Universitario, 1, 47011 Valladolid, Spain, e-mail: ana@emp.uva.es, ORCID: 0000-0002-7554-7639

${ }^{3}$ Universidad de Valladolid, Facultad de Comercio, Departamento de Economía Financiera y Contabilidad, Plaza del Campus Universitario, 1, 47011 Valladolid, Spain, e-mail: mariano@emp.uva.es, ORCID: 0000-0003-3881-4010
}

(c) 2018 by the authors; licensee Review of Economic Perspectives / Národohospodářský obzor, Masaryk University, Faculty of Economics and Administration, Brno, Czech Republic. This article is an open access article distributed under the terms and conditions of the Creative Commons Attribution 3.0 license, Attribution - Non Commercial - No Derivatives. 
With the aim of gaining a deeper understanding of specific economic sectors, their companies' financial structure and even financial efficacy in recent years, a number of studies have been conducted that resort to financial ratios that draw upon accounting information provided by the companies themselves. The techniques of financial analysis have been applied in this way on numerous sectors of the economy, such as the banking sector (Gómez-Borrero, 1986), Spain's electricity sector (González et al. 2013), the wine industry (Arimany et al. 2016) and several others.

In the literature, we can find a fair number of studies on ratio-based business bankruptcy prediction, including those by Alfaro et al. (2008); Holsapple and Wu (2011); Lee et al. (1996); Martín-Oliver and Salas-Fumás (2012); Olson et al. (2012) and Wilson and Sharda (1994). Few contributions, however, focus on the evolution of ratios over time or in connection with the typology of companies involved. Serrano et al. (2005) use multivariate analysis techniques in order to assess the effects of company size and country on financial profitability; Costa and Carini (2016) explore differences regarding output and employment in Italian cooperative businesses by means of several analyses that factor in the geographical regions where the companies are based, while Delen et al. (2013) perform an exploratory factor analysis to identify the dimensions underlying a set of financial ratios and subsequently use decision tree algorithms to evaluate the impact of these dimensions on business results.

The use of synthetic indexes is becoming increasingly common, particularly in the public sector, but also, in more recent times, in private sectors. In our country, there are specific cases where they have been employed for purposes such as the evaluation of sustainable tourism in Andalusia (Blancas et. al., 2010), the assessment of the olive sector's sustainability in the same region (Gómez-Limón and Arriaza, 2011), or, once again, an analysis of sustainability in the tourism sector at large (Thiel and Navarro, 2013).

The purpose of this paper is to build a financial performance synthetic index on the basis of profitability and solvency ratios of EU-28 companies operating in the publishing sector in years 2012 and 2014. Our paper's original contribution lies in using composite or synthetic indexes to compare the efficiency of these companies for the above designated period and ascertain whether or not the companies' size, age, geographical location or legal status have a bearing on their financial performance.

The remaining part of this paper is structured as follows: the following section collects information on the publishing sector in Europe that provides the main data on the sector; the third section focuses on the research design by identifying the data sources, describing the study population and outlining the several stages needed to produce a synthetic index; the fourth section is devoted to presenting the paper's results in their various aspects; finally, the paper closes with a section devoted to conclusions as well as a list of the bibliographical references used.

\section{The publishing sector in Europe}

Cultural industries in Europe constitute a relevant economic sector: one that is even ahead of other sectors such as the energy business or agriculture. In 2010, creative industries contributed roughly $4.5 \%$ to the gross value added of the then EU-27 - more 
specifically, $6.5 \%$ in the United Kingdom, $4.9 \%$ in France, $4.2 \%$ in Germany, $3.8 \%$ in Italy and 3.6\% in Spain. The percentages of those employed in cultural industries out of all employed show a correlation with the above, with a global $3.8 \%$ for the whole of EU-27 and member states percentages as follows: 5.4\% in the United Kingdom, 3.7\% in France, $4.1 \%$ in Germany, 3.6\% in Italy and 3.5\% in Spain (Tera Consultants, 2010).

Furthermore, the publishing industry is the subsector that generates the greatest wealth within the entire range of cultural industries. To mention a single example, data for the United Kingdom are revealing, because in 2014, the nominal contribution of the British publishing sector to the gross value added increased by $2.8 \%$ compared with the previous year and has increased by an average of $1.6 \%$ year over year in the period 2008 2013 (Creative Industries Council 2014). According to data supplied by the Federation of European Publishers (FEP 2015), the total revenue obtained in 2014 by book publishers in the 28 countries making up the European Union amounted to $€ 22$ billion, while the number of full-time employees working in this industry reached 125,000 . In comparison with 2012 , there was a decrease both in revenue $(2.22 \%)$ and in employment $(3.85 \%)$, while the publication of new titles rose $(1.87 \%)$, as well as the number of titles in print (active catalogue) (87.78\%). Since the slowdown of 2009 has ended, the sector's growth over the last few years has been tied to an increase in exports, the licensing of translation rights and sales of e-books.

The publishing industry has a large potential thanks to opportunities afforded by technological advances and development of communications, but it also faces numerous problems, as it is forced to quickly adapt to changes in the population's consumption patterns. According to predictions made in a report titled Global Entertainment and Media Outlook: 2013-2017 elaborate by PricewaterhouseCoopers (2013), it is expected that by 2017 , digital media will represent $37 \%$ of all advertising revenue, in contrast with their share of $26 \%$ in 2012, while purchased physical books will only account for $53 \%$ of consumers' total spending. The publishing industry is introducing innovations in its production models and combating piracy and unfair competition.

Regarding the sector's legislation, there are differences in prices and VAT rates applicable across EU countries. In most of them, however, the price of books is regulated through so-called fixed price agreements. As an example, we may mention the Loi 81/766, of 10 August 1981 in France, and Ley 10/2007, of 22 June 2007 on reading, books, and libraries in Spain, as well as Decreto-Lei 176/96, of 21 September 1996 in Portugal. These countries include Austria, Denmark, Germany, Greece, Hungary, Italy, the Netherlands, Portugal, France and Spain, which thus subscribe to the official position of the European Parliament. Fixed price laws establish that publishers are entitled to fix the price of books, which must then remain identical in all sales points, notwithstanding the possibility of applying discounts of a maximum of about 5\%, the exception being book fairs and sales to public libraries. On the other hand, some countries resort to a free price system. Among them are Belgium, Finland, Ireland, Luxembourg, the United Kingdom, Sweden and Switzerland, where there is opposition to protectionist measures in the cultural sector. A controversial issue in most countries, however, is the VAT rate applicable to printed and digital books as regulated by Directive 2008/8/EC, which claims that an electronic book is a digital download service which must be taxed at rates between $18 \%$ and $21 \%$, while printed books have reduced VAT rates in all 
countries with the exception of Denmark (25\%). In 2015, France and Luxembourg changed their tax rate to $20 \%$ and $17 \%$, respectively, following a ruling by the European Union's Court of Justice after several years of recurring breaches of European law.

An important attribute of this sector is its degree of concentration, both in geographical and business terms. According to the report The Global Ranking of the Publishing Industry (Rüdiger Wischenbart Content \& Consulting, 2015), in 2014, the top 57 publishing groups accumulated revenue worth $€ 59,328$ million, i.e. $11 \%$ more than in 2013 , while the 10 largest groups alone earned $€ 31,820$ million. In 2014 , the most powerful European markets were Germany, the United Kingdom, France, Spain and Italy, whose total market value is estimated at $€ 36-38$ billion. On the other hand, even though numerous companies are based in these countries, it is only a small number of them that dominate the market, the remainder being occupied by a large number of small and medium-sized businesses. For example, in Germany, the big companies with total sales worth over $€ 50$ million take up nearly $70 \%$ of the sector's total revenue; in Spain, $4 \%$ of the largest firms represent over $64 \%$ of the industry's turnover; in the United Kingdom, over $50 \%$ of companies have annual sales figures below $£ 100,000$. In the French book distribution sector, the top five companies have a combined market share of $50 \%$.

\section{Research design}

After this bird's eye view of the publishing sector in Europe, we will conduct an empirical analysis of available financial data corresponding to a selection of European companies. This section details the analysed population as well as the sources of financial data used, and describes the method for building a synthetic index using the multivariate procedure of factorial analysis.

\subsection{Study population and data sources}

The data have been extracted from Amadeus (2016), a database compiled by Bureau Van Dijk, and therefore do not constitute a random sample of all EU-28 companies. However, they do provide valuable economic and financial information on a set of 2,356 businesses.

The editorial sector contains great disparities among the companies that make it up. For this reason, and in order to work with companies that are as homogeneous as possible, we decided to include in the sample only those whose operating revenue was above $€ 1,000,000$ in the year 2014. Moreover, we singled out those companies for which we had data concerning all ratios employed in the factor analysis for the years 2012 and 2014 - i.e., the data we would need in order to define their financial performance index. Based on these criteria, we were eventually left with a total number of 794 businesses.

\subsection{Constructing synthetic or composite indexes}

The construction of composite indexes has been used for some time now in multiple public management tasks such as those involving the economy and social development. More generally, the procedure has been employed in many instances of scientific research (Saisana and Tarantola, 2002; Munda, 2005; Nardo et al. 2008). 
Pertaining methodology, we need to construct a function containing several variables that can together measure a single characteristic in the individual items under scrutiny (Schuschny and Soto, 2009). As for the reasons that justify the use of synthetic indexes, these would have to do with "the ability to sum up and interpret information as well as to evaluate in a simple way complex and multidimensional phenomena" [our translation] (Blancas et al., 2010, p.3). The use of indexes does not only make it possible to summarise a set of data, but moreover, it enables us to observe tendencies in the situation that is being studied, analyse their evolution over time and even make future predictions. This in turn allows us to make comparisons or establish rankings, both over time (longitudinal) and at specific points in time (cross-sectional).

One of the most common criticisms of this approach is that it involves subjective choices by the analyst along the several stages of the process: singling out the simple indicators to work with, normalising data or setting up a weighting system are compulsory tasks which no doubt involve prior connotations and may bias results in one direction or another. This is why it is critical to reduce such subjectivity as much as possible by employing a methodology that enables us to cut down on the number of decisions to be made by the analyst (Munda, 2005). It also becomes particularly relevant to explain in a clear and precise way the process whereby the index is constructed, thus facilitating the understanding of final results.

Adhering to recommendations of several authors (Boulanger, 2009; Nardo et al., 2005; OECD, 2008), the present paper proposes the following stages in the construction of a composite index: conceptual framework, variable identification and selection, measuring, weighting, aggregating and disseminating results.

In our case, the aim is to construct a synthetic index that represents the financial performance (FPI) of companies in the publishing sector of EU-28. This index will then be used to conduct a series of further studies on the similarities and differences that can be found in the sector itself. The starting point was to define a series of variables or subindicators that portray the financial situation of the companies under scrutiny. Table 1 features the variables' code and name as well as their description, both in the case of variables used in constructing the index and also of variables that will later be used to conduct specific studies.

The weight assignment procedure poses some challenges, since it is in this part of the process where a possibly biased approach may produce significant differences among the indicators thus obtained, which would in turn weaken their validity (Nardo et al. (2005). Multivariate techniques provide adequate solutions and, more particularly, principal component analysis - i.e., the method chosen for the purposes of this researcheliminates redundant information by correcting overlaps that may exist between two or more variables. On the above-mentioned initial data, we applied a factor analysis whereby factors were extracted by principal components in order to conduct the weighting procedure using percentages of explained variance. 


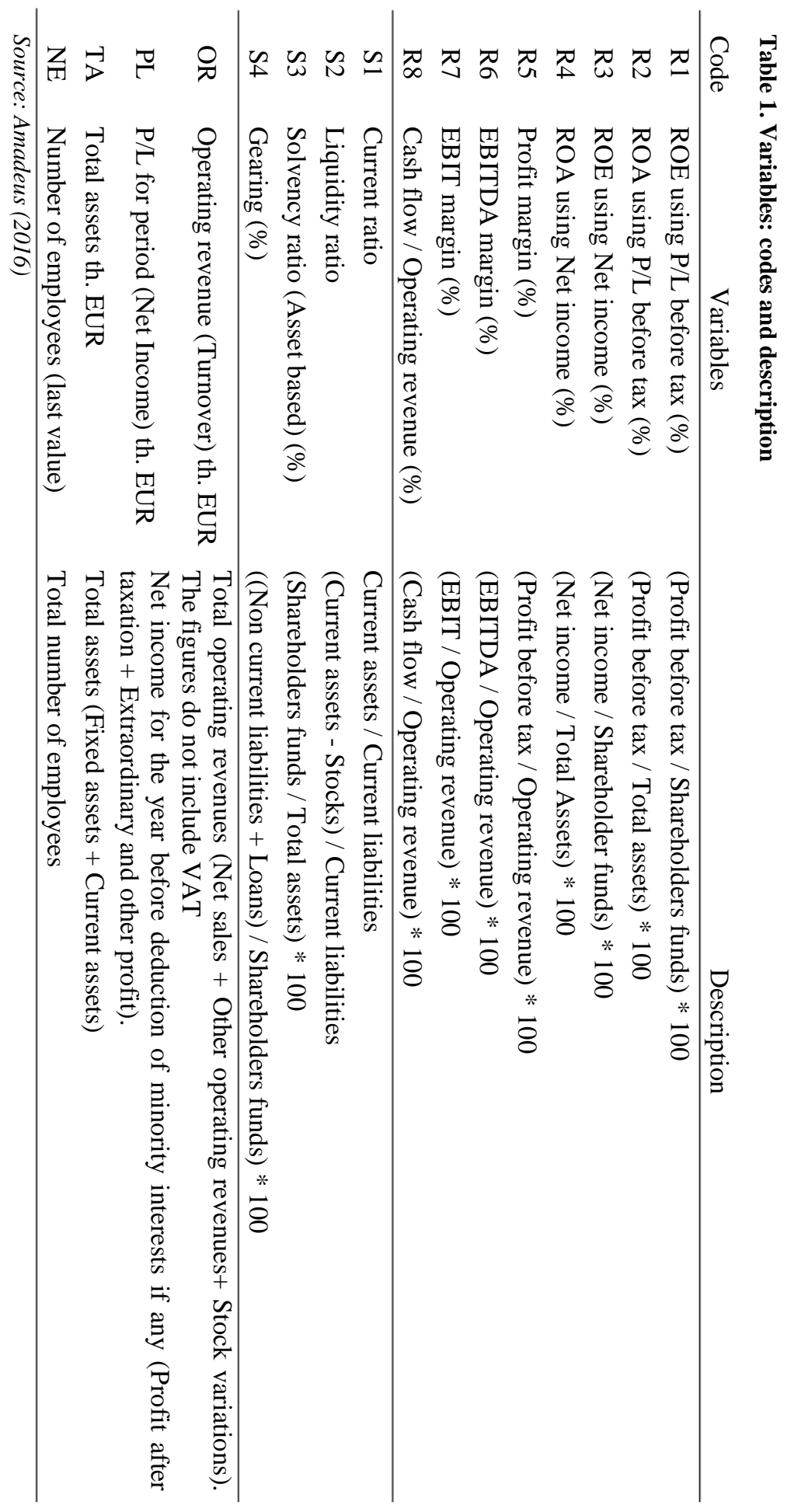


In the aggregation stage, additive and multiplicative methods are the most typical - the weighted sum of indicators being the most common (Gómez-Limón and Arriaza, 2011). In our case, we have used the following formula:

$F P I=\sum_{i=1}^{j} F S_{i} x w_{i}$

Where $\mathrm{FS}_{\mathrm{i}}$ are factor scores obtained by each company in each of the components defined, while $\mathrm{w}_{\mathrm{i}}$ is the percentage of explained variance of each component.

$w_{i}=\frac{\text { Explained variance for each component }}{\sum_{i=1}^{j} \text { explained var.of the whole set of selected components }}$

Once indexes have been calculated for each company and every year, the combined information is provided in a summarised and compiled form.

\section{Results}

We now present the results, commencing with a general descriptive analysis of the firms' financial data and defining the interest groups so as to interpret the index. The results of the factorial analysis are then provided and used to build the synthetic index. The section concludes with an analysis of the financial performance index from various standpoints: depending on the type of firm and the quintile of the indicator.

\subsection{Initial analysis}

In this section, we will present the sector's aggregated data. First, a joint study is conducted, where the values of all variables are presented in a systematic, summary-like form. Second, we divide the assessed companies into several groups according to four different typologies.

\section{a) Descriptive analysis}

Table 2 and Table 3 show a descriptive study of the analyzed variables. A first look at the data shows that Pearson's coefficients of variation are very high, which points to a large dispersion for all variables. By comparing average values for the two years under scrutiny, we observe that all profitability ratios for 2014 rose when compared to 2012, that is with the exception of the two ratios related to the ROE variable. Profit margin saw the highest increase $(9.70 \%)$, whereas the most important drop was that of the ROE variable when estimated on the basis of net income (12.79\%). As regards structural ratios, the only increase takes place in the solvency ratio, while the liquidity ratio remains stable and both the current ratio and financial gearing undergo a decrease, which is more pronounced $(8.46 \%)$ in the latter case. Regarding size-related variables, profits in 2014 increased compared to $2012(4.30 \%)$, as did total assets $(2.53 \%)$, while the average values for both operating revenue and number of employees dropped. 
Table 2. Descriptive analysis 2014

\begin{tabular}{cccccccc} 
& $\mathrm{N}$ & Mean & Median & Std. Dev. & Coeff. Var. $(\%)$ & Minimum & Maximum \\
\hline R114 & 794 & 15.90 & 10.54 & 48.57 & 305.49 & -394.43 & 439.24 \\
R214 & 794 & 6.47 & 4.14 & 12.21 & 188.73 & -43.60 & 82.14 \\
R314 & 794 & 9.41 & 6.90 & 41.73 & 443.71 & -394.43 & 408.73 \\
R414 & 794 & 4.50 & 3.01 & 9.97 & 221.58 & -46.07 & 56.34 \\
R514 & 794 & 5.88 & 4.10 & 11.87 & 201.97 & -50.85 & 53.52 \\
R614 & 794 & 8.83 & 7.25 & 11.72 & 132.79 & -46.60 & 53.87 \\
R714 & 794 & 5.75 & 4.63 & 10.98 & 190.99 & -46.94 & 51.06 \\
R814 & 794 & 7.16 & 5.76 & 10.99 & 153.44 & -46.60 & 52.00 \\
\hline S114 & 794 & 2.67 & 1.80 & 2.80 & 104.81 & 0.24 & 34.11 \\
S214 & 794 & 2.03 & 1.30 & 2.35 & 115.69 & 0.03 & 22.36 \\
S314 & 794 & 46.44 & 44.35 & 24.15 & 52.01 & 1.08 & 97.06 \\
S414 & 794 & 60.69 & 17.62 & 107.52 & 177.16 & 0.00 & 814.36 \\
\hline OR14 & 794 & 20315.70 & 3622.20 & 90155.20 & 443.77 & 1001.09 & 1793000.00 \\
PL14 & 794 & 1492.23 & 105.23 & 13670.10 & 916.08 & -22743.60 & 345482.00 \\
TA14 & 794 & 25944.70 & 4109.99 & 114885.00 & 442.81 & 155.47 & 2214800.00 \\
NE14 & 665 & 93.41 & 22.00 & 470.17 & 503.33 & 1.00 & 8554.00 \\
\hline
\end{tabular}

Source: Own elaboration

Table 3. Descriptive analysis 2012

\begin{tabular}{lccccccc} 
& $\mathrm{N}$ & Mean & Median & Std. Dev. & Coeff. Var. (\%) & Minimum & Maximum \\
\hline R112 & 794 & 16.13 & 11.29 & 52.96 & 328.32 & -391.76 & 587.48 \\
R212 & 794 & 6.03 & 4.27 & 12.30 & 203.90 & -52.79 & 87.51 \\
R312 & 794 & 10.79 & 7.82 & 43.24 & 400.80 & -341.10 & 428.08 \\
R412 & 794 & 4.33 & 2.95 & 10.18 & 235.13 & -48.87 & 72.45 \\
R512 & 794 & 5.36 & 3.75 & 12.02 & 224.19 & -74.13 & 66.39 \\
R612 & 794 & 8.31 & 6.85 & 11.93 & 143.47 & -52.42 & 67.69 \\
R712 & 794 & 5.36 & 4.41 & 11.14 & 207.96 & -56.23 & 63.21 \\
R812 & 794 & 6.79 & 5.45 & 11.19 & 164.79 & -59.73 & 67.54 \\
\hline S112 & 794 & 2.73 & 1.81 & 3.08 & 112.80 & 0.09 & 30.41 \\
S212 & 794 & 2.03 & 1.32 & 2.45 & 120.32 & 0.03 & 25.29 \\
S312 & 794 & 45.80 & 44.69 & 24.63 & 53.77 & 1.35 & 97.73 \\
S412 & 794 & 66.30 & 18.57 & 123.45 & 186.19 & 0.00 & 998.30 \\
\hline OR12 & 794 & 21747.80 & 3512.01 & 103767.00 & 477.14 & 289.53 & 1995700.00 \\
PL12 & 794 & 1430.71 & 90.13 & 8955.46 & 625.95 & -22075.90 & 128900.00 \\
TA12 & 794 & 25305.40 & 3934.03 & 112829.00 & 445.87 & 126.17 & 2143500.00 \\
NE12 & 637 & 94.68 & 21.00 & 512.00 & 540.77 & 1.00 & 10152.00 \\
\hline
\end{tabular}

Source: Own elaboration 


\section{b) Group analysis}

In order to gain a deeper understanding of the index's meaning, we will use classificatory variables with several characteristics measuring company age, location, size and legal form in order to analyse how the index changes in each of the groups under consideration.

Company age (Age_Cod) will be recoded into three categories: 15 years or below, between 15 and 30 years and over 30 years. Such a classification is warranted due to the fact that the companies in this sector tend to be quite old. For this reason, we decided to group together all businesses below the age of 15 (i.e., recently created companies together with those with a somewhat longer history); and at the opposite end, we have grouped companies above the age of 30 , including 13 firms that exceed the 100 year mark.

The geographical region (Coun_Cod) where the company is based is another variable where we have established groups as follows: Region 1 (Mediterranean) includes Spain, Greece, Italy and Portugal; Region 2 (Central Europe) is made up of Germany, Austria, Belgium, France, Ireland, Luxembourg, the Netherlands and the United Kingdom; Region 3 (Northern Europe) consists of Estonia, Finland, Latvia and Sweden; and Region 4 (Eastern Europe) groups together Croatia, Slovakia, Slovenia, Hungary, Poland and the Czech Republic.

In order to analyze size, the variable that will be used measures the company's total assets over a given year. This has been recoded into four groups: assets of $€ 5$ million or less, between $€ 5$ and $€ 10$ million, between $€ 10$ and $€ 50$ million and over $€ 50$ million.

Finally, the company's legal form has been recoded into three subcategories: Private limited companies, Public limited companies and other legal forms — the last including the remaining types and making up a very small group.

Table 4 shows the values whereby the several variables have been subdivided into groups as well as the number of companies making up each of these groups.

Table 4. Classificatory variables: values and number of companies

\begin{tabular}{cc|cc|cc|cc} 
Age_Cod & N & Coun_Cod & N & TA_Cod (th. $€$ ) & N & Legal_Form & N \\
\hline$\leq 15$ & 234 & Region 1 & 330 & $\leq 5000$ & 452 & Private & 477 \\
$15-30$ & 291 & Region 2 & 315 & $5000-10000$ & 115 & Public & 284 \\
$>30$ & 269 & Region 3 & 53 & $10000-50000$ & 160 & Other & 33 \\
& & Region 4 & 96 & $>50000$ & 67 & & \\
\hline
\end{tabular}

Source: Own elaboration

\subsection{Factor analysis and index construction}

The approach of this part of the research consists in performing a principal component analysis of the initial information matrix provided by 794 companies and 12 variables for the years 2014 and 2012, and then using the results of this analysis to construct a financial performance index for each year. 
The Kaiser-Meyer-Olkin measure of sampling adequacy shows values of 0.572 and 0.547 respectively for years 2014 and 2012, while the p-values yielded by Bartlett's test of sphericity are clearly lower than 0.05 . On the other hand, the communalities and the principal diagonal of the anti-image correlation matrices exhibit high values, which suggests that we should not exclude any variable from the analysis. The reproduced correlation matrix reflects percentages of non-redundant residuals at $16 \%$ and $22 \%$ respectively for the years 2014 and 2012, which confirms the goodness-of-fit of our analysis. All measures and indexes obtained by means of this method confirm its validity and the inclusion of all variables used, there being no need to exclude any of them.

Based on the 12 initial variables, and adhering to Kaiser's criterion, our factor model extracts four factors that explain $89.417 \%$ of the total variance for the year 2014 and $88.664 \%$ for 2012 . Table 5 includes the eigenvalues for each factor as well as the percentages of both the explained variance for each factor and the cumulative variance. In Table 6 we can see the factors' coefficients after the varimax rotation.

Table 5. Percentages of explained variance 2014 and 2012

\begin{tabular}{ccccccc} 
& \multicolumn{5}{c}{ Initial } & \multicolumn{5}{c}{ Rotation Sums of Squared Loadings } \\
\hline Component & 2014 & 2012 & $\begin{array}{c}\text { \% of vari- } \\
\text { ance } 2014\end{array}$ & $\begin{array}{c}\text { Cumula- } \\
\text { tive \% 2014 }\end{array}$ & $\begin{array}{c}\text { \% of variance } \\
\text { Eigenvalues }\end{array}$ & $\begin{array}{c}\text { Cumulative \% } \\
2012\end{array}$ \\
\hline 1 & 5.970 & 5.746 & 39.660 & 39.660 & 37.871 & 37.871 \\
2 & 2.593 & 2.598 & 19.157 & 58.816 & 20.385 & 58.256 \\
3 & 1.142 & 1.267 & 19.027 & 77.844 & 18.813 & 77.069 \\
4 & 1.026 & 1.030 & 11.574 & 89.417 & 11.595 & 88.664 \\
5 & .435 & .491 & & & & \\
6 & .301 & .318 & & & & \\
7 & .235 & .260 & & & & \\
8 & .134 & .138 & & & & \\
9 & .095 & .075 & & & & \\
10 & .050 & .063 & & & & \\
11 & .016 & .014 & & & & \\
12 & .005 & .003 & & & & \\
\hline
\end{tabular}

Extraction method: Principal component analysis.

Source: Own elaboration

Bearing in mind the variables' correlations with the extracted factors, our interpretation of the latter for the year 2014 would be as follows:

F1. Business profitability: this factor is highly correlated with ratios R2, R4, R5, R6, R7 and R8. It measures operating or sales profitability, as well as the gross margin resulting from operations.

F2. Liquidity: this factor is correlated with $\mathrm{S} 1$ and $\mathrm{S} 2$, which indicate cash availability. 
F3. Financial profitability or shareholder value: this factor is highly correlated with ratios R1 and R3.

F4: Solvency: this factor bears a positive correlation with the solvency ratio S3 and a negative correlation with gearing S4.

Table 6. Rotated component matrix

\begin{tabular}{|c|c|c|c|c|c|c|c|c|c|}
\hline & \multicolumn{4}{|c|}{ Component 2014} & & \multicolumn{4}{|c|}{ Component 2012} \\
\hline & 1 & 2 & 3 & 4 & & 1 & 2 & 3 & 4 \\
\hline R614 & .941 & & & & R612 & .937 & & & \\
\hline R714 & .929 & & & & R712 & .920 & & & \\
\hline R514 & .914 & & & & R512 & .915 & & & \\
\hline R814 & .884 & & & & R812 & .899 & & & \\
\hline R214 & .770 & & & & R212 & .712 & & & \\
\hline R414 & .754 & & & & R412 & .705 & & & \\
\hline S114 & & .977 & & & R312 & & .931 & & \\
\hline S214 & & .970 & & & R112 & & .925 & & \\
\hline R314 & & & .918 & & S112 & & & .970 & \\
\hline R114 & & & .908 & & S212 & & & .964 & \\
\hline S414 & & & & -.948 & S412 & & & & -.944 \\
\hline S314 & & & & .646 & S312 & & & & .639 \\
\hline
\end{tabular}

Extraction method: Principal component analysis.

Rotation method: Varimax with Kaiser normalisation.

Rotation converged in 5 iterations for 2014 and in 6 iterations for 2012.

Source: Own elaboration

For the year 2012, the factors remain the same, the only difference being the order in which they appear, with the second and the third factor swapping places. This, however, has no effect on index construction.

Once this factor analysis has been conducted, we proceed in estimating the synthetic index by using the formula described above. Since the values originally obtained in the index are not expressed on a representative scale and differ for the two years being studied, the next step consists in normalising the index so that it varies from 0 to 100 . This is achieved by using the following formula:

$F P I N=\frac{F P I-\min (F P I)}{\max (F P I)-\min (F P I)} \times 100$

Since we have been working with a very large sample of companies (794), we next provide a synthetic summary of the information in Table 7 and in Figure 1, which shows the number of operating companies in each of the 5 score ranges - going from the lowest value (0) to the highest one (100) — following index normalisation. 
Table 7. Number of entities by score range

\begin{tabular}{cccccc} 
Groups & Index range & N 2014 & $\%$ 2014 & N 2012 & $\% 2012$ \\
\hline Group 1 & $0-20$ & 19 & 2.39 & 11 & 1.38 \\
Group 2 & $20-40$ & 183 & 23.05 & 80 & 10.08 \\
Group 3 & $40-60$ & 487 & 61.33 & 540 & 68.01 \\
Group 4 & $60-80$ & 92 & 11.59 & 143 & 18.01 \\
Group 5 & $80-100$ & 13 & 1.64 & 20 & 2.52 \\
\hline
\end{tabular}

Source: Own elaboration

Figure 1. Number of entities by score range

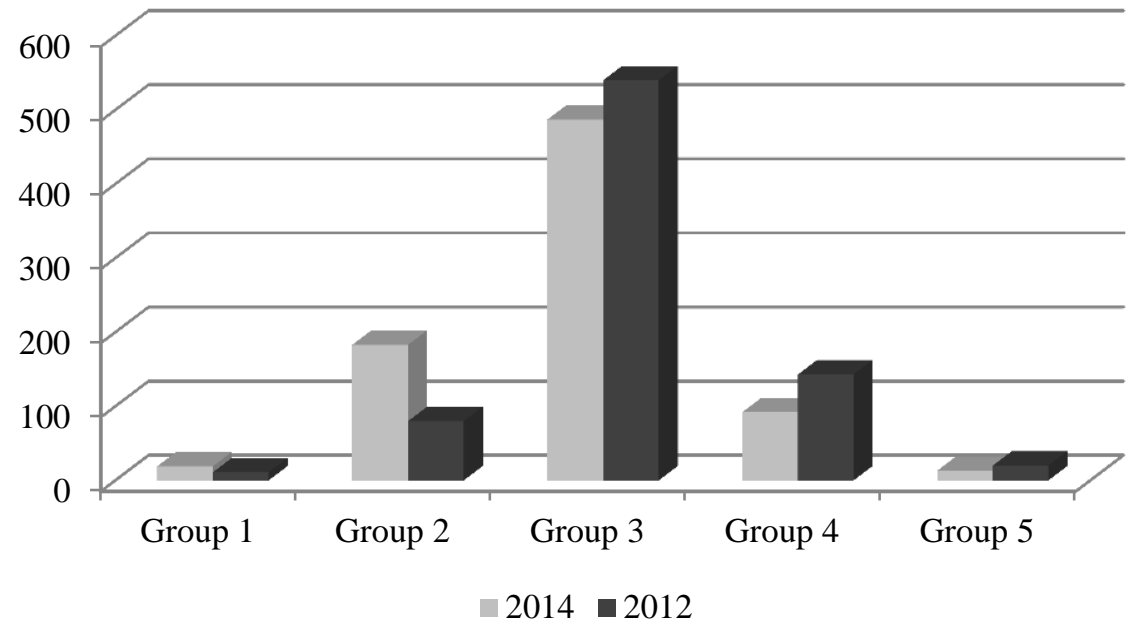

Source: Own elaboration

\subsection{Analysis of the financial performance index (FPI)}

Once the index has been obtained, we will conduct two different types of analyses for the years being studied. First, we will compare the mean indexes based on several variables such as age, geographic region, total assets and legal form, in order to identify significant differences within these categories and trace their evolution. In our second analysis, we will group together the index values in quintiles and examine their influence on the variables profits-and-losses and number of employees.

a) Analysis of FPI by company type

The age variable only shows significant differences at the $10 \%$ level for the mean index of the three categories defined - and this only in figures for 2014. Such differences are not significant in 2012, as can be seen in Table 12. Table 8 shows that the index decreases as company age increases. 
Table 8. Summary Statistics for Company Age

\begin{tabular}{cccccc} 
Age_Cod & $\mathrm{N}$ & Mean 2014 & Median 2014 & Mean 2012 & Median 2012 \\
\hline$\leq 15$ & 234 & 47.9467 & 45.0551 & 52.2251 & 50.1836 \\
$15-30$ & 291 & 47.1435 & 45.6035 & 51.4258 & 49.8419 \\
$>30$ & 269 & 45.5312 & 45.4386 & 50.7869 & 50.4098 \\
\hline Total & 794 & 46.8340 & 45.5278 & 51.4449 & 50.1439 \\
\hline
\end{tabular}

Source: Own elaboration

In the case of geographical regions or zones where we have grouped together several sets of countries, Table 12 shows that in the two years observed by our study, there are significant differences across regions. In both years, the geographical region that exhibits the clearest differences compared with the rest is region 4, with higher indexes than the others. The others, in turn, share values that are closer to one another as can be seen in Table 9, which also demonstrates that region 2 has experienced a slight decrease, with mean values below those of region 3 .

Table 9. Summary Statistics for Geographic Region

\begin{tabular}{cccccc} 
Coun_Cod & N & Mean 2014 & Median 2014 & Mean 2012 & Median 2012 \\
\hline Region 1 & 330 & 45.6721 & 44.0172 & 49.6943 & 48.2671 \\
Region 2 & 315 & 45.9522 & 44.7188 & 52.2401 & 50.8002 \\
Region 3 & 53 & 46.5994 & 47.9978 & 51.3309 & 52.4625 \\
Region 4 & 96 & 53.8507 & 50.1035 & 54.9165 & 51.8169 \\
\hline Total & 794 & 46.8340 & 45.5278 & 51.4449 & 50.1439 \\
\hline
\end{tabular}

Source: Own elaboration

Regarding total assets, Table 12 illustrates that there are no significant differences among the indexes for the four groups that were defined. While not significant, however, it is worth mentioning that the mean values of the created indexes increase as total assets grow, with the exception of a small "swap" of values occurring between the two middle categories for the year 2014, as can be seen in Table 10.

Table 10. Summary Statistics for Total Assets

\begin{tabular}{cccccc} 
TA_Cod (th. $€$ ) & $\mathrm{N}$ & Mean 2014 & Median 2014 & Mean 2012 & Median 2012 \\
\hline$\leq 5000$ & 452 & 45.8941 & 44.4053 & 50.6379 & 49.1500 \\
$5000-10000$ & 115 & 48.4046 & 48.2243 & 51.3860 & 49.1188 \\
$10000-50000$ & 160 & 47.6930 & 47.4109 & 52.9598 & 52.6470 \\
$>50000$ & 67 & 48.4271 & 47.9901 & 53.5351 & 52.1557 \\
\hline Total & 794 & 46.8340 & 45.5278 & 51.4449 & 50.1439 \\
\hline
\end{tabular}

Source: Own elaboration 
As far as legal form is concerned, values in Table 12 show that in this variable as well, no significant differences occur across indexes corresponding to the several legal forms that companies may have. Table 11 indicates that the greatest difference regarding the legal forms considered here occurs within the group "Other Legal Forms", which exhibits the biggest drop between the years 2012 and 2014.

Table 11. Summary Statistics for Legal Form

\begin{tabular}{cccccc} 
Legal_Form & N & Mean 2014 & Median 2014 & Mean 2012 & Median 2012 \\
\hline Private & 477 & 47.3908 & 45.4386 & 52.1085 & 50.3282 \\
Public & 284 & 46.3323 & 46.5594 & 50.1934 & 50.0688 \\
Other & 33 & 43.1036 & 44.3589 & 52.6228 & 50.1087 \\
\hline Total & 794 & 46.8340 & 45.5278 & 51.4449 & 50.1439 \\
\hline
\end{tabular}

Source: Own elaboration

Table 12. Statistics for equality of variance and equality of means/medians contrasts. Company age, Geographical Region, Total Assets and Legal Form

\begin{tabular}{cccccc} 
Variable & Factor & Levene & P-value & F Ratio & P-value \\
\hline \multirow{2}{*}{ Age_Cod } & FPIN14 & 0.0638 & 0.9382 & 2.31 & $0.0996^{*}$ \\
& FPIN12 & 0.2898 & 0.7485 & 0.77 & 0.4629 \\
\multirow{2}{*}{ Coun_Cod } & FPIN14 & 1.7927 & 0.1471 & 11.18 & $0.0000^{* * *}$ \\
& FPIN12 & 3.2314 & $0.0219 * *$ & $18.39^{\mathrm{a}}$ & $0.0004^{* * *}$ \\
TA14_Cod & FPIN14 & 1.4044 & 0.2402 & 1.93 & 0.1224 \\
TA12_Cod & FPIN12 & 0.4894 & 0.6897 & 1.88 & 0.1306 \\
& FPIN14 & 6.7620 & $0.0012 * * *$ & $2.10^{\mathrm{a}}$ & 0.3504 \\
Legal_Form & FPIN12 & 1.9625 & 0.1412 & 2.09 & 0.1240 \\
\hline
\end{tabular}

${ }^{a}$ Kruskal-Wallis statistic is used.

* Significant at 10\%, ** Significant at 5\%, *** Significant at $1 \%$.

Source: Own elaboration

b) FPI quintiles: their influences on variables profits-and-losses and number of employees

In our second analysis, we have split up our sample of companies into quintiles obtained using the 2014 index and subsequently focused on the mean values of two additional variables inside each of the quintiles: profits-and-losses and number of employees. In order for all information to refer to the same companies, we will only use index values for the year 2014. Regarding the profits-and-losses variable, Table 13 shows a mean increase of $€ 61,520$ in company profits from 2012 to 2014 -i.e., a $4.30 \%$ rise. However, a closer inspection of information within the quintiles reveals a decrease of mean profits in the first four quintiles between the years 2012 and 2014, especially in the first two quintile (792.61\% in the first and $66.85 \%$ in the second). In the last quintile, there is a marked increase $(64.47 \%)$. In both years, and both for mean and median values, we 
observe an increase as we move into a higher quintile (see Table 13): in other words, the higher the index is, the larger the companies' profits are. These differences are statistically significant, as is made evident in Table 15. Another observation that corroborates a strong positive correlation between the obtained index and the variable reflecting profits and losses is the fact that Spearman's rank correlation coefficient is 0.7352 for the year 2014 and 0.7547 for the year 2012 .

Table 13. Summary Statistics for Profits-and-Losses

\begin{tabular}{cccccc} 
QUIN14 & N & Mean 2014 & Median 2014 & Mean 2012 & Median 2012 \\
\hline 1 & 159 & -750.256 & -106.673 & 94.656 & 2.661 \\
2 & 159 & 243.178 & 23.331 & 733.474 & 29.943 \\
3 & 158 & 1293.060 & 106.263 & 1595.670 & 90.284 \\
4 & 159 & 1393.160 & 270.658 & 1519.960 & 163.931 \\
5 & 159 & 5280.770 & 616.476 & 3210.830 & 454.367 \\
\hline Total & 794 & 1492.230 & 105.231 & 1430.710 & 90.134 \\
\hline
\end{tabular}

Source: Own elaboration

On the other hand, between 2012 and 2014, there was a 2.81\% decrease in employment (see Table 14) in the companies making up the study sample (an occurrence that, as was mentioned in this paper's introduction, is shared by the whole of the companies in the sector). Such a decrease, however, is not equally distributed but rather depends on the quintile a given firm's index for 2014 occupies. In other words, companies included in the first four quintiles did experience a decrease in their number of employees, although there are differences among them, since companies in the third quintile experienced a bigger drop in this regard with staff cuts equivalent to $10.77 \%$, in contrast with the $3 \%$ observed in the other three quintiles. However, companies with a high index increased their staff by $9.68 \%$. The high degree of dispersion exhibited by this variable within every single quintile defined for the purpose of this study means that these differences between values in the several quintiles are not statistically significant, as is shown in Table 15.

Table 14. Summary Statistics for Number of Employees

\begin{tabular}{cccccc} 
QUIN14 & $\mathrm{N}$ & Mean 2014 & Median 2014 & Mean 2012 & Median 2012 \\
\hline 1 & 131 & 50.244 & 19.0 & 52.710 & 18.0 \\
2 & 118 & 100.890 & 23.0 & 105.059 & 23.0 \\
3 & 119 & 139.790 & 20.0 & 156.664 & 18.0 \\
4 & 121 & 68.736 & 26.0 & 69.752 & 27.0 \\
5 & 122 & 118.377 & 25.5 & 107.926 & 26.5 \\
\hline Total & 611 & 94.732 & 22.0 & 97.466 & 22.0 \\
\hline
\end{tabular}

Source: Own elaboration 
Table 15. Statistics for equality of variance and equality of means/medians contrasts. Profits-and-Losses and Number of Employees

\begin{tabular}{ccrrrr} 
Variable & Factor & Levene & P-value & Kruskal-Wallis & \multicolumn{1}{c}{ P-value } \\
\hline PL14 & QUIN14 & 8.2786 & $0.0000^{* * *}$ & 432.34 & $0.0000^{* * *}$ \\
PL12 & QUIN14 & 4.6030 & $0.0011^{* * *}$ & 159.98 & $0.0000 * * *$ \\
NE14 & QUIN14 & 1.9698 & $0.0976^{*}$ & 4.35 & 0.3606 \\
NE12 & QUIN14 & 2.2544 & $0.0620^{*}$ & 3.71 & 0.4472
\end{tabular}

* Significant at 10\%, ** Significant at 5\%, *** Significant at $1 \%$.

Source: Own elaboration

\section{Conclusions}

Cultural industries have consolidated their position in Europe as an outstanding economic sector, both from the point of view of gross value added and in respect of employment. Within these cultural industries, it is the publishing sector that contributes the greatest wealth, providing full-time jobs in EU-28 for 125,000 people and generating a total revenue worth $€ 22$ billion. A distinctive characteristic of this sector is its high degree of both geographic and business concentration.

With the aim of studying the publishing sector, this paper has defined a synthetic index that measures the financial performance of companies in this sector. In order to construct such an index, we have singled out a number of profitability and structural ratios that collect information on the financial situation of the companies under scrutiny from several points of view.

Our first analysis of the data showed that between 2012 and 2014, there was a widespread increase in profitability ratios — with the exception of ROE—, solvency, profits and total assets. Gearing, operating revenues and the number of employees experienced a decrease.

In order to create the financial performance index, factor analysis boils down the information provided by the initial 12 ratios into 4 new factors that account for nearly $90 \%$ of the total variance for each of the two years targeted by our study, so that the index meets reliability standards. These new factors are: business profitability, financial or shareholder value, liquidity and solvency. The results obtained show that the majority of companies reach index scores within the central interval; about $70 \%$ of them fall into this interval.

As for the analysis by business type, the constructed financial performance index shows differences regarding company age, the highest values being reached by the youngest companies. There are also significant differences in connection with the geographical regions where companies are based, with Eastern Europe (Croatia, Slovakia, Slovenia, Hungary, Poland and the Czech Republic) standing out from the rest. In terms of size, there are no significant differences between the defined categories, even though it may be observed that when the companies' total assets rise, so does their FPI. As regards legal form, no significant differences were detected. 
Moreover, when the FPI is grouped into quintiles and its influence on other variables is analyzed, the results obtained for profits and losses show significant differences across quintiles, where the highest scoring companies achieve the best results - an occurrence that is completely consistent with the index's meaning. When the same effect is analyzed from the point of view of employment, it turns out that the companies with the highest index are the only ones that have increased their staff numbers, while the rest have lost jobs in all cases, albeit not following a single pattern.

As a final conclusion, we may argue that the main contribution of this paper is the design of a model for evaluating financial performance in companies within the publishing sector that has enabled us to measure the efficiency of each business with regard to the rest while keeping in mind its profitability and financial structure variables.

The technique used to construct the synthetic indicator proves to be robust and is supported by a number of applications in other fields of research. One prominent future line of research may thus involve this type of study being replicated over time in an effort to examine the stability of the results obtained in the publishing sector. It may also be applied to firms in any other financial sector, comparing the outcomes with those that emerge here.

Disclosure statement: No potential conflict of interest was reported by the authors.

\section{References}

ALFARO, E., GARCÍA, N., GÁMEZ, M. and ELIZONDO D. (2008). Bankruptcy forecasting: An empirical comparison of AdaBoost and neural networks. Decision Support Systems, 45(1), 110-122. DOI: 10.1016/j.dss.2007.12.002.

AMADEUS [Database] (2016). Brussels etc.: Bureau van Dijk Electronic Publishing.

ARIMANY, N., FARRERAS, A. and RABASEDA, J. (2016). Análisis económico financiero del sector vinícola de la Rioja en un entorno de crisis. Intangible capital, 12(1), 268-294. DOI: $\underline{10.3926 / \text { ic.686. }}$.

BLANCAS, F.J., CONTRERAS, I. and RAMÍREZ, J.M. (2010). Construcción de indicadores sintéticos para maximizar la discriminación. Anales de ASEPUMA, 19, 123. [Actas de las XIX Jornadas de Asepuma-VII Encuentro Internacional]. Available at https://goo.gl/fFzxvf.

BOULANGER, P.M. (2008). Sustainable development indicators: a scientific challenge, a democratic issue. Surveys and Perspectives Integrating Environmental and Society, 1(1), 45-59.

COSTA, E. and CARINI, C. (2016). Northern and southern Italian social cooperatives during the economic crisis: a multiple factor analysis. Service Business, 10(2), 369-392. DOI: $10.1007 / \mathrm{s} 11628-015-0274-1$.

CREATIVE INDUSTRIES COUNCIL (2014). Publishing Facts and Figures. Available at https://goo.gl/dKsGrL. 
DECRETO-LEI N. ${ }^{\circ}$ 176/96, of 21 September 1996, Institui o regime do preço fixo do livro [Portugal]. Diário da república, September 21, 1996, n. 220/96 Série I-A, 33093313.

DELEN, D., KUZEY, C. and UYAR, A. (2013). Measuring firm performance using financial ratios: A decision tree approach. Expert Systems with Applications, 40(10), 3970-3983. DOI: 10.1016/j.eswa.2013.01.012.

DIRECTIVE 2008/8/EC, of 12 February 2008. Official Journal of the European Union, February 20, 2008, L44 11-22.

FEDERATION OF EUROPEAN PUBLISHERS (FEP) (2015). European Book Publishing Statistics 2014. Available at https://goo.gl/JYbXSn.

GÓMEZ-BORRERO, J.C. (1986). El análisis financiero en el sector bancario. Revista Española de Financiación y Contabilidad, 49, 257-272.

GÓMEZ-LIMÓN, J.A. and ARRIAZA, M. (2011). Evaluación de la sostenibilidad de las explotaciones de olivar en Andalucía. Málaga: Analistas Económicos de Andalucía. [XIII Premio Unicaja de Investigación Agraria]. Available at https://goo.gl/Y2Wtda.

GONZÁLEZ, S., IBÁÑEZ, E., JIMÉNEZ, L. and VÁZQUEZ, I. (2013). El sector eléctrico español. Análisis económico financiero en 2013. Análisis Financiero, 123, 4572 .

HOLSAPPLE, C.W. and WU, J. (2011). An elusive antecedent of superior firm performance: The knowledge management factor. Decision Support Systems, 52(1), 271-283. DOI: $\underline{10.1016 / j . d s s .2011 .08 .003}$.

INTERNATIONAL PUBLISHERS ASSOCIATION (IPA) (2015). Annual Report: October 2014 - October 2015. Available at http://goo.gl/HHkRmb.

LEE, K.C., HAN, I. and KWON, Y. (1996). Hybrid neural network models for bankruptcy predictions. Decision Support Systems, 18(1), 63-72. DOI: 10.1016/01679236(96)00018-8.

LEY 10/2007, of 22 June 2007, de la lectura, del libro y de las bibliotecas [España]. Boletín Oficial del Estado, June 23, 2007, n. 150, 27140-27150.

LOI $\mathrm{N}^{\circ}$ 81-766, of 10 August 1981, relative au prix du livre [France]. Journal officiel de la République française, August, 11, 1981, 2198.

MARTÍN-OLIVER, A. and SALAS-FUMÁS, V. (2012). IT assets, organization capital and market power: Contributions to business value. Decision Support Systems, 52(3), 612-623. DOI: 10.1016/j.dss.2011.10.019.

MUNDA, G. (2005). Measuring sustainability: a multi-criterion framework. Environment. Development and Sustainability, 7(1), 117-134. DOI: 10.1007/s10668-003-4713$\underline{0}$.

NARDO, M., SAISANA, M., SALTELLI, A. and TARANTOLA, S. (2005). Tools for Composite Indicators Building. EUR 21682 EN, Ispra, Italy: European Commission, Joint Research Centre, Institute for the Protection and Security of the Citizen, Econometrics and Statistical Support to Antifraud Unit. Available at http://goo.gl/9eFMqD. 
OECD (2008). Handbook on constructing composite indicators. Methodology and User Guide. Paris: OECD Publications.

OLSON, D.L., DELEN, D and MENG, Y. (2012). Comparative analysis of data mining methods for bankruptcy prediction. Decision Support Systems, 52(2), 464-473. DOI: 10.1016/j.dss.2011.10.007.

PRICEWATERHOUSECOOPERS S.L. (2013). Global entertainment and media outlook 2013-2017. Available at http://goo.gl/VukmWm.

RÜDIGER WISCHENBART CONTENT \& CONSULTING (2015). The Global Ranking of the Publishing Industry. Available at http://goo.gl/9uBXcd.

SAISANA, M. and TARANTOLA, S. (2002). State-of-the-art Report on Current Methodologies and Practices for Composite Indicator Development. EUR 20408 EN, Ispra, Italy: Joint Research Centre (JRC) European Commission.

SCHUSCHNY, A. and SOTO, H. (2009). Guía metodológica: diseño de indicadores compuestos de desarrollo sostenible. Comisión Económica para América Latina y el Caribe (CEPAL), Naciones Unidas. Santiago de Chile.

SERRANO, C., MAR, C. and GALLIZO, J.L. (2005). Country and size effects in financial ratios: A European perspective. Global Finance Journal, 16 (1), 26-47. DOI: 10.1016/j.gfj.2005.05.003.

TERA CONSULTANTS (2010). Building a Digital Economy: The Importance of Saving Jobs in the EU's Creative Industries. Available at http://goo.g1/31Kog2.

THIEL, D. and NAVARRO, E. (2013). Metodología para la construcción de indicadores sintéticos de sostenibilidad aplicados al turismo: revisión de estudios y nuevas propuestas. XII Jornadas nacionales de Investigación en turismo. Ushuaia, Argentina.

WILSON, R.L. and SHARDA, R. (1994). Bankruptcy prediction using neural networks. Decision Support Systems, 11(5), 545-557. DOI: 10.1016/0167-9236(94)90024-8. 